УДК 614.253.4(071)+34:61

\title{
ОРГАНІЗАЦІЯ ДИСТАНЦИЙНОГО НАВЧАННЯ СТУДЕНТІВ НА КАФЕДРІ МЕДИЧНОГО ПРАВА
}

\author{
М. В. Чорненький, К. М. Махобей, М. О. Сопіга \\ ДВНЗ “Тернопільський держсавний медичний університет \\ імені I. Я. Горбачевського МОЗ України”
}
ORGANIZATION OF DISTANT TRAINING OF STUDENTS ON THE DEPARTMENT OF MEDICAL LAW

\author{
M. V. Chornenky, K. M. Makhobei, M. O. Sopiha \\ SHEI "Ternopil State Medical University by I.Ya.Horbachevsky of MPH of Ukraine"
}

\begin{abstract}
Стаття розкриває переваги дистанційного навчання спеціалістів медичного профілю, а також особливості використання методу на кафедрі медичного права Тернопільського державного медичного університету імені І. Я. Горбачевського.

This article focuses on the benefits of distant training medical professionals as well as the specials of this method usage on the Department of Medical Law of Ternopil State Medical University by I. Ya. Horbachevsky.
\end{abstract}

Вступ. Незважаючи на низку недоліків, з кожним днем дистанційне навчання набуває все більшої популярності серед студентів і викладачів. Адже воно має чимало переваг. Так, дистанційна освіта дозволяє економити час, навчатись у будь-якому (зручному) місці, у будь-який (зручний) час, у комфортній обстановці. Крім того, такий вид навчання має переваги у використанні новітніх освітніх технологій.

Дистанційна освіта особливо актуальна для викладачів, яким у сучасних умовах вкрай необхідне постійне навчання для підвищення кваліфікації [1]. В тому числі активно використовується дистанційне навчання з метою навчання і підвищення кваліфікації медичного персоналу - як лікарів, так і медсестер [2].

Основна частина. Згідно із Положенням про дистанційне навчання, затвердженим наказом Міністерства освіти і науки України 25.04.2013 року № 466, під дистанційним навчанням розуміється індивідуалізований процес набуття знань, умінь, навичок і способів пізнавальної діяльності людини, який відбувається в основному за опосередкованої взаємодії віддалених один від одного учасників навчального процесу у спеціалізованому середовищі, яке функціонує на базі сучасних психолого-педагогічних та інформаційнокомунікаційних технологій [3].

Метою дистанційного навчання $€$ надання освітніх послуг шляхом застосування у навчанні сучасних

() М. В. Чорненький, К. М. Махобей, М. О. Сопіга інформаційно-комунікаційних технологій за певними освітніми або освітньо-кваліфікаційними рівнями відповідно до державних стандартів освіти; за програмами підготовки громадян до вступу у навчальні заклади, підготовки іноземців та підвищення кваліфікації працівників. Завданням дистанційного навчання $€$ забезпечення громадянам можливості реалізації конституційного права наздобуття освіти та професійної кваліфікації, підвищення кваліфікації незалежно від статі, раси, національності, соціального і майнового стану, роду та характеру занять, світоглядних переконань, належності до партій, ставлення до релігії, віросповідання, стану здоров'я, місця проживання відповідно до їх здібностей.

У Тернопільському державному медичному університеті дистанційне навчання активно застосовується у навчальному процесі студентів НHI медсестринства для здобуття освітньо-кваліфікаційних рівнів бакалавра за спеціальністю 6.120101 "Сестринська справа", магістра за спеціальністю 8.12010006 “Сестринська справа”. Організація процесу дистанційного навчання регламентується Положенням про дистанційне навчання в Тернопільському державному медичному університеті імені І. Я. Горбачевського, затвердженим наказом ректора університету від 29.05.2009 року [4]. Дане Положення розроблене відповідно до Положення про дистанційне навчання, затвердженого наказом Міністерства освіти і науки України від 21.01.2004 року № 40 [5]. 
Дистанційне навчання в університеті реалізується через Центр дистанційного навчання, який $є$ структурним підрозділом університету з нормативно-правовою базою, організаційно оформленою структурою, кадровим, матеріально-технічним та фінансовим забезпеченням. Основним завданням Центру дистанційного навчання $€$ реалізація дистанційного навчання на рівні вищої та післядипломної освіти.

Викладачі кафедри медичного права здійснюють дистанційне навчання з дисципліни "Правознавство та медичне законодавство" українською та англійською мовами для обох освітньо-кваліфікаційних рівнів, для яких розроблені відповідні робочі програми [6-9]. Метою курсів $є$ вивчення специфічних особливостей правового регулювання тих питань, які відносяться до діяльності закладів охорони здоров'я, медичних працівників. Передбачено викладання таких галузей та інститутів права, 3 якими медичні працівники зустрічаються найчастіше у своій практичній діяльності. Це, перш за все, конституційне, адміністративне, цивільне, кримінальне, трудове право тощо.

Робоча програма для освітньо-кваліфікаційного рівня бакалавр включає один модуль із загальною кількістю 54 години. 3 них аудиторні години: 18 годин лекційних занять та 12 годин практичних занять; а також 24 години самостійної позааудиторної роботи. Курс $з$ дисципліни "Правознавство та медичне законодавство" також складається з одного модуля iз загальною кількістю 108 годин. 3 них аудиторні години: 10 годин лекційних занять та 24 години практичних занять; а також 74 години самостійної позааудиторної роботи.

Перед початком дисципліни викладач розміщує на веб-сайті університету всі необхідні для підготовки студентів матеріали: робочу програму з оновленим згідно із розкладом планом, методичні вказівки до практичних занять, презентації лекцій, матеріали для підготовки до занять, тестові запитання в системі Moodle. Перевірка наявності та відповідності вказаних матеріалів вимогам здійснюється персоналом Центру дистанційної освіти.

Контактування викладача зі студентами відбувається через електронну пошту, а також Skype. За один день до початку дисципліни викладач надсилає студенту лист з інформацією про початок вивчення нової дисципліни, розміщення навчальних матеріалів за встановленим зразком. У день практичного заняття викладач надсилає студенту лист із вказуванням теми заняття та теоретичними запитаннями (чи ситуаційними задачами), на які студент повинен відповісти до встановленого терміну (рекомендовано до двохтрьох днів, термін відповіді вказується у листі).

У процесі викладання курсів передбачено два види контролю, а саме: поточний - на семінарських (практичних) заняттях та підсумковий. Поточний контроль виставляється за вирішення тестових завдань у системі Moodle та участь у практичній та семінарській частинах заняття (у журналі виставляється чотири оцінки, остання з яких - загальна і вираховується як середня арифметична 3 трьох попередніх).

Студенти, які не мають заборгованості з лекцій та практичних занять, допускаються до підсумкового контролю, який відбувається у вигляді диференційованого заліку.

Для підвищення якості дистанційного навчання викладацький склад кафедри медичного права постійно працює над підвищенням своїх знань у галузі медичного правознавства, українського та зарубіжного медичного законодавства, професійних навичок, рівня володіння іноземною (англійською) мовою.

3 цією метою було проведено двотижневе навчання викладачів кафедри на курсах “Автоматизація навчальних технологій” при Тернопільському державному технічному університеті імені Івана Пулюя. Курси загальною тривалістю 80 годин включали такі теми: "Методичні аспекти контролю знань за допомогою електронних навчальних засобів" (9 годин), “Загальна інформація” (11 годин), "Робота 3 текстами” (11 годин), “Керування курсом” (12 годин), “Робота зі студентами” (12 годин), “Техніка формування лекційних матеріалів" (13 годин), "Практичні рекомендації по організації навчального курсу" (12 годин).

Висновки. Дистанційне навчання медичних кадрів має ряд переваг серед інших новітніх навчальних технологій, що дозволяє його ефективно використовувати як для навчання, так і підвищення кваліфікації.

У Тернопільському державному медичному університеті, в тому числі кафедрою медичного права, ефективно використовуються можливості дистанційного навчання для здобуття освітньо-кваліфікаційних рівнів бакалавра й магістра за спеціальністю “Сестринська справа". 3 цією метою розроблені та затверджені відповідні робочі програми та методичні рекомендації.

Навчально-педагогічні курси сприятимуть покращенню інформативності, доступності та економічній ефективності освіти, яку надає Тернопільський державний медичний університет імені І. Я. Горбачевського, зокрема кафедра медичного права. 


\section{Список літератури}

1. Твердохлєбова Н. Є. Дистанційне навчання як система підвищення кваліфікації сучасного викладача / Н. С. Твердохлєбова, С. О. Семенов // Восточно-Европейский журнал передовых технологий. -2013. - № 2/2 (62). - С. 25-29.

2. Боярська Л. М. Технології дистанційного навчання лікарів-педіатрів / Л. М. Боярська, О. А. Рижов, Ю. В. Котлова // Актуальні питання дистанційної освіти та телемедицини - 2013 : матеріали Всеукраїнської науково-методичної конференції, 10-11 жовтня 2013 року. - С. 87-88.

3. Про затвердження Положення про дистанційне навчання : наказ Міністерства освіти і науки України від 25.04.2013 року № 466 .

4. Про затвердження Положення про дистанційне навчання в Тернопільському державному медичному університеті імені І. Я. Горбачевського : наказ ректора Тернопільського державного медичного університету імені І. Я. Горбачевського від 29.05.2009 року.
5. Про затвердження Положення про дистанційне навчання : наказ Міністерства освіти і науки Українивід 21.01.2004 року №40.

6. Правознавство та медичне законодавство : робоча програма $з$ дисципліни для здобуття освітньо-кваліфікаційного рівня бакалавр за спеціальністю 6.120101 “Сестринська справа".

7. Правознавство та медичне законодавство : робоча програма $з$ дисципліни для здобуття освітньо-кваліфікаційного рівня магістр за спеціальністю 8.12010006 “Сестринська справа".

8. Law and Medical Legislation: the syllabus on the discipline for obtaining bachelor's degree on nursing 6.120101.

9. Law and Medical Legislation: the syllabus on the discipline for obtaining master's degree on nursing 8.12010006.

Отримано 23.12.14 